\title{
Grain Yield of Maize Hybrids in Response to Inoculation with Azospirillum sp. under Nitrogen Limiting Conditions in Huaura, Peru
}

\author{
Elin Teodoro-Cerna ${ }^{1}$, Eroncio Mendoza-Nieto ${ }^{2} \&$ Sergio Eduardo Contreras-Liza ${ }^{2}$ \\ ${ }^{1}$ Graduate student, Universidad Nacional Jose Faustino Sanchez Carrion, Huacho, Peru \\ ${ }^{2}$ Department of Agronomy, Universidad Nacional Jose Faustino Sanchez Carrion, Huacho-Lima, Peru \\ Correspondence: Sergio Eduardo Contreras-Liza, Universidad Nacional Jose Faustino Sanchez Carrion, Av. \\ Mercedes Indacochea 608, Huacho-Lima, Peru. Tel: 511-971-759-585. E-mail: scontreras@ unjfsc.edu.pe
}

Received: September 14, 2020 Accepted: October 17, 2020 Online Published: November 5, 2020

doi:10.5539/sar.v10n1p1

URL: https://doi.org/10.5539/sar.v10n1p1

\begin{abstract}
This experiment was conducted to evaluate the effect of Azospirillum sp. inoculated with different nitrogen levels $\left(0,60,90,180 \mathrm{~kg} \mathrm{ha}^{-1}\right)$ on grain yield, yield components and agronomic traits of hybrid maize at the arid conditions of the central coast of Peru. The experimental design used was randomized complete block design with four replications per treatment, under the arrangement of subdivided plots, in which three corn hybrids were assigned to complete plots and four inoculant- $\mathrm{N}$ fertilization treatments, to the subplots. The results showed that for dose fertilization of $180 \mathrm{~kg} \mathrm{ha}^{-1}$ of nitrogen (control), the grain yield of hybrid corn was similar as compared to $60-120 \mathrm{~kg} \mathrm{ha}^{-1} \mathrm{~N}$ fertilization inoculated at 15 and 45 days with a native strain of Azospirillum sp., suggesting that the response in grain yield for hybrid corn can be balanced with nitrogen fertilization and inoculation with Azospirillum sp. $1 \times 10^{8} \mathrm{CFU} \mathrm{mL} \mathrm{m}^{-1}$ in conditions of arid soils, with possible impact on the use of this microorganism in the maize production system
\end{abstract}

Keywords: nitrogen fertilization, Azospirillum, grain yield, maize

\section{Introduction}

The coast of Peru is a low-elevation plain adjacent to the Pacific Ocean and influenced by the cold Humboldt Current. It is a hyper-arid biome mostly devoid of vegetation, with the exception of the fog-dependent plant communities ('Lomas') and groundwater (Polk et al. 2020). In Peru, the area of corn under cultivation exceeds half a million hectares, of which 265,000 are planted with hard yellow corn (Ministerio de Agricultura y Riego, 2017), being a product of high demand in the agricultural and industrial market, mainly in the poultry and pig industry. The average grain yield in corn is $10 \mathrm{tha}^{-1}$ in the department of Lima (Sistema Integrado de Estadística Agraria, 2020); however, production does not manage to supply national demand (Cabrera-Chavez, 2020). Corn remains in Peru because the agribusiness demands twice the volume produced in the country, through the operation of an agri-food chain (Eguren, 2003).

Maize is one of the world's most important agricultural products (Ngoune \& Mutengwa, 2020), is generally planted in monoculture and can be held responsible for shaping the agricultural environment (Peiffer et al., 2013). Nitrogen recommendations for corn planting are less precise than desired and must be improved for economic and environmental reasons (Morris et al., 2018). With the exception of water resources, nitrogen is the most important limiting factor in the productivity of this crop (Franca et al., 2011). Globally, fertilizers support approximately $40 \%$ of the current world population and consume about $2 \%$ of the world's available energy supply (Reis et al., 2020).

Biofertilizers are defined as formulations of live microbial strains that are applied to seeds, plants or soil to colonize the rhizosphere, improving the supply and availability of nutrients and that can totally or partially replace fertilizers (Schmidt and Gaudin, 2018). Among plant-associated microorganisms, the mutualistic symbionts of fungi and bacteria have evolved successfully with their hosts since plants adapted to terrestrial ecosystems; they promote plant growth by facilitating the acquisition of scarce nutrients (Martin et al., 2017). The best-known example of a symbiotic association that can reduce the use of nitrogen fertilizers is that of bacteria and legumes that fix $\mathrm{N}_{2}$. Bacterial taxa that are not rhizobia species can also develop associative symbiotic interactions with plants and fix atmospheric nitrogen. These include bacteria of the genera 
Azospirillum, Azotobacter, and Bacillus, some of which are marketed as bio-inoculants (Dellagi et al., 2020).

The use of plant growth-promoting bacteria for the formulation of biofertilizers has become one of the most promising clean technologies for the development of sustainable agriculture (Gouda et al., 2017). Inoculants containing plant growth-promoting bacteria represent a new strategy to increase the efficiency of nitrogen use (NUE), providing better plant nutrition and grain yield in corn (Galindo et al. 2020). The genus Azospirillum has the ability to fix atmospheric nitrogen, solubilize phosphorus, produce cytokinins, gibberellins and auxins, which allows it to be used as a biofertilizer to obtain agricultural products, without generating consequences in the environment (Perez-Montano et al., 2013). Nitrogen-fixing microbial associations are efficient and well-characterized in legumes but are limited in cereals, including corn (Van Deynze et al., 2018).

Plant growth-promoting bacteria are considered a green technology that reduces the use of chemical fertilizers, thus improving soil health (Ramakrishna et al., 2019). Since the levels of nitrogen fixation achieved with nitrogen-fixing bacteria in cereals are not high enough to satisfy the needs of the plant and not as effective as those obtained with chemical fertilizers, it is a current research objective to increase nitrogen fixation in cereals, including corn (Rosenblueth et al., 2018). Schmidt \& Gaudin (2018) found greater efficacy for biological nitrogen fixation in corn with strains of Azospirillum sp. than with Bacillus sp. and Enterobacter sp., under field conditions.

According to Walters et al. (2018), some local varieties of corn grown in Mexico under traditional agricultural practices with little or no fertilizer could have developed strategies to improve plant performance under conditions of low nitrogen content in the soil. In these local varieties of the $29 \%$ to $82 \%$ assimilated nitrogen, is derived from the atmospheric form $\mathrm{N}_{2}$. Bennett et al. (2020) proposed a model for the association of nitrogen-fixing microbes with the mucilage of the rhizosphere of corn and identified the main functionalities of a productive diazotrophic association.

Piscoya \& Ugaz (2016) demonstrated that the application of diazotrophic bacteria and 50\% of chemical fertilizer increases the height of the plant, the number of leaves and the diameter of the stem as well as the grain yield in hard yellow corn. According to Zambonin et al. (2019), no interaction was found between the hybrids and inoculation for the variables studied and the specificity between the hybrids and the inoculation was not verified. Likewise, they found that inoculation with A. brasilense did not interfere with grain yield and maize yield components. Alvarado et al. (2018), mention that the joint use of synthetic fertilizers with microbial inoculants maintained or increased grain yields compared to those obtained with only synthetic fertilization in 18 varieties of corn.

Munaretto et al. (2019) found that foliar application of A. brasilense, either alone or combined with seed treatment, increased grain yield and yield components of wheat cultivars. Reyes et al (2018) concluded that the use of the biofertilizer A. brasilense represented a $28 \%$ increase in corn grain yield. Silva et al. (2020) observed physiological responses when inoculants of corn root exudates were used, although these effects varied according to the genotype of the plant and the source of the exudates, finding that soluble compounds exudated by corn seedlings can increase the colonization by A. brasilense. Inoculation with A. brasilense increased Nitrogen Use Efficiency (NUE), maize grain yield and agronomic characteristic in the AS 1572 hybrid (Skonieski et al., 2019) also, there was no response in another hybrid; the use of this diazotrophic bacterium is viable even when high rates of N were applied (Galindo et al., 2016). However, Schaefer et al. (2019) considered that $A$. brasilense helps plant growth and yield but does not replace the effect of $\mathrm{N}$ fertilization.

Correa-Galeote et al. (2016) suggested that the genotype of Andean starchy maize could be the main factor in controlling bacterial diversity in its rhizosphere, either in monoculture or in association with other plants. The results of Wagner et al. (2020) show that interactions with soil microorganisms are important for the expression of heterosis in corn. Recently, SCAR-type molecular markers have been developed for the identification of $A$. brasilense (Coniglio et al. 2020).

There is a need for a biofertilizer development framework that integrates information from the soil microbial community and prioritizes validation of results in the field. To elucidate the roles of microbiomes in host performance, selection can be applied via contrasting treatments, in addition to controls (Mueller \& Sachs, 2015). The objective of the work was to evaluate the effect of a native strain of Azospirillum sp. under nitrogen limiting conditions on the yield of hybrid corn, in the central coast of Peru.

\section{Materials and Method}

\subsection{Description of Experimental Location}

The research was carried out in the experimental field of the National University Jose Faustino Sanchez Carrion 
located in Huacho (Lima), geographic coordinates $11^{\circ} 07^{\prime} 26^{\prime \prime} \mathrm{S}, 77^{\circ} 36^{\prime} 32^{\prime \prime} \mathrm{W}$. During the development of the experiment (spring 2018) the climatic conditions in the coast of Peru were average temperature of $20.1^{\circ} \mathrm{C}$, minimum temperature of $13.1{ }^{\circ} \mathrm{C}$, maximum temperature of $22.7^{\circ} \mathrm{C}$ and relative humidity of $73-79 \%$. No rainfall is recorded in this agroecosystem, with relatively cold and arid conditions prevailing along the Pacific coast that extends to the western slopes of the Andes (Garreud, 2009).

Two soil samples at 0 and $30 \mathrm{~cm}$ depth from the soil surface were collected prior to soil preparation and various physicochemical properties were analyzed during the growing season, as presented in Table 1. The characterization analysis shows that the experimental place presented a soil without salinity problems, moderately alkaline, with very low content of soil organic matter $(\mathrm{OM})$, low in phosphorus $(\mathrm{P})$, medium in potassium (K).

Table 1. Soil characterization analysis in the experimental site

\begin{tabular}{|c|c|c|c|c|c|c|c|c|c|c|c|c|c|c|c|c|}
\hline No. & $\begin{array}{l}\mathrm{EC} \\
\mathrm{dS} / \mathrm{m}\end{array}$ & $\begin{array}{l}\text { Clay } \\
\%\end{array}$ & $\begin{array}{l}\text { Lime } \\
\%\end{array}$ & $\begin{array}{l}\text { Sand } \\
\%\end{array}$ & $\mathrm{pH}$ & $\begin{array}{l}\mathrm{CaCO}_{3} \\
\%\end{array}$ & $\begin{array}{l}\mathrm{OM} \\
\%\end{array}$ & $\begin{array}{l}\mathrm{P} \\
\mathrm{ppm}\end{array}$ & $\begin{array}{l}\mathrm{K} \\
\mathrm{ppm}\end{array}$ & CIC & $\begin{array}{l}\mathrm{B} \\
\mathrm{ppm}\end{array}$ & $\mathrm{NO}_{3}$ & $\mathrm{Ca}+$ & $\mathrm{Mg}+$ & $\begin{array}{l}\text { PSI } \\
\% \\
\end{array}$ & $\begin{array}{l}\text { Textural } \\
\text { Class }\end{array}$ \\
\hline 1 & 1.4 & 82 & 14 & 4,0 & 8.37 & 4.4 & 0.4 & 10.6 & 165 & 6.88 & 1.3 & 0.45 & 6.87 & 2.58 & 5.66 & $\begin{array}{l}\text { Sandy } \\
\text { loam }\end{array}$ \\
\hline \multirow[t]{2}{*}{2} & 2.15 & 83 & 13 & 4,0 & 8.23 & 4.1 & 0.5 & 7.8 & 177 & 5.92 & 2.1 & 0.68 & 17.95 & 4.33 & 7.77 & $\begin{array}{l}\text { Sandy } \\
\text { loam }\end{array}$ \\
\hline & 1.78 & 82 & 14 & 4,0 & 8.3 & 4.25 & 0.45 & 9.2 & 171 & 6.4 & 1.7 & 0.57 & 12.41 & 3.46 & 6.72 & \\
\hline
\end{tabular}

\subsection{Plant Materials}

The bacterial strain used in the research was isolated from the maize rhizosphere in cultivated fields of the central coast of Peru and identified as Azospirillum sp. by the Laboratorio de Biotecnología de la Produccion (National University Jose Faustino Sanchez Carrion), by morphological characterization and biochemical profile (catalase $^{+}$test, urease ${ }^{+}$reaction, motility test and oxidase ${ }^{+}$test). The biomass of the bacterial strain was increased in a nutrient broth and it was quantified in Colony Forming Units (CFU) obtaining an inoculum concentration of $1 \times 10^{8} \mathrm{CFU} \mathrm{mL}{ }^{-1}$. The inoculation was carried out by spraying the foliage after the emergence of maize 15 days after sowing) and at the time of hilling (45 days after sowing), according to the indicated treatments; herbicides were not applied to avoid interactions in the soil with the inoculating agent.

The inoculant treatments were applied to three commercial cultivars of yellow corn; these were the hybrids 'Agricol XB8010', 'Dekalb 7508' and 'INIA 619', which were randomly distributed for sowing, in each replication. These corn cultivars are popular and often used by farmers under the growing conditions of the central coast of Peru.

\subsection{Experimental Design, Layout and Treatments}

The experimental design used was that of random complete blocks with four replications per treatment, under the arrangement of subdivided plots, in which the corn hybrids were assigned to complete plots and the inoculant treatments, to the subplots. The experimental units were randomly assigned for each treatment within each variety and had a dimension of 4 rows of 10 meters long. For the evaluations, only the two central rows were taken into account, to avoid the effect of edges.

Nitrogen $(\mathrm{N})$ treatments were formulated in decreasing form for fertilization, being coded according to Table 2 . The urea source $(46 \% \mathrm{~N})$ was used, applied 15 and 45 days after sowing, according to each level of $\mathrm{N}$ considered. These nitrogen treatments coincided with the applications of the inoculant Azospirillum sp. when it corresponded to the indicated combinations $\left(\mathrm{T}_{1}, \mathrm{~T}_{2}, \mathrm{~T}_{3}\right)$. The control treatment $\left(\mathrm{T}_{0}\right.$, without inoculation) was applied with the complete dose of 180 units of nitrogen per hectare, also fractionating the fertilizers at 15 and 45 days after sowing. $\mathrm{P}$ and $\mathrm{K}$ levels were constant for all treatments.

Table 2 Inoculant and $\mathrm{N}$-fertilization treatments used in the field experiment

\begin{tabular}{ll}
\hline Code & Treatments (N-P-K) \\
\hline $\mathrm{T}_{0}$ control & $180-100-150$ no inoculated \\
$\mathrm{T}_{1}$ & $120-100-150+$ Azospirillum $\mathrm{sp}$ \\
$\mathrm{T}_{2}$ & $60-100-150+$ Azospirillum $\mathrm{sp}$. \\
$\mathrm{T}_{3}$ & $00-100-150+$ Azospirillum $\mathrm{sp}$. \\
\hline
\end{tabular}

\subsection{Cultural Practices}

A planting density of 65000 plants per hectare $(0.90 \times 0.40 \mathrm{~m})$ was used in the field experiment. Irrigation to the 
field was by furrows with a weekly frequency, from emergence to harvest maturity, which occurred 150 days after sowing. The control treatment (without inoculation) was applied with the complete dose of 180 kilos of nitrogen per hectare, fractionating the fertilizer 15 and 45 days after sowing. Herbicides were not applied to avoid interactions in the soil with the inoculating agent.

\subsection{Data Collection}

The agronomic characters evaluated were: percentage of emergence in the field 10 days after sowing $(\% \mathrm{E})$, the number of leaves per plant (NLP), length of leaves (LL), average width of the leaf (LW), stem diameter (SD), fresh weight of foliage at 30 days (FW30), fresh weight of foliage at 60 days (FW60), fresh weight of foliage at 90 days (FW90), dry weight of foliage at 30 days (DW30), foliage dry weight at 60 days (DW60).

The yield components evaluated were: number of ears per sample (NM), average fresh weight of ear (FWE, transformed data), the diameter of the ear (ED), the diameter of the stem (SD), length of the ear (EL), the weight of 100 seeds (WS), average dry weight of cob (DWC), dry weight of grain per plant (DWG, transformed data), percentage of survival to harvest (\% S), yield grain per hectare (YG).

To evaluate each variable in the experiment, random samples were taken from each treatment. With the exception of the grain yield per hectare in which the ears were weighed and shelled in the two central furrows of each experimental unit, in the rest of the variables 10 plants were randomly taken for each sample per treatment.

\subsection{Statistical Analysis}

The data were processed using the Infostat program (2017 version), performing the analysis of variance and the Scott-Knott test to compare the treatment means, at a significance level of 5\%.

\section{Results}

\subsection{Grain Yield and its Components}

In the analysis of variance, it can be observed that regarding the grain yield per hectare, statistical differences were found for the inoculant treatments, but not for the corn hybrids (Table 3). Differences were found also between inoculant treatments for the following performance components: ear and cob diameter, ear length, the weight of 100 seeds and dry weight of the cob. Regarding the maize hybrids evaluated, the significant effects corresponded to the number of ears, fresh weight of the ear per plant, length of ear, the weight of 100 seeds and dry weight of the crown. In the case of ear length, a significant interaction was also found between corn hybrids and inoculant treatments, showing specific effects for this trait.

Table 3. Analysis of Variance for yield components

\begin{tabular}{|c|c|c|c|c|c|c|c|c|c|c|c|}
\hline \multicolumn{12}{|c|}{ MS (Yield components) } \\
\hline $\begin{array}{l}\text { Sources of } \\
\text { Variation }\end{array}$ & dF & $\begin{array}{l}\mathbf{N E} \\
\mathrm{n}\end{array}$ & $\begin{array}{l}\text { FWE }^{+} \\
\text {g plant }\end{array}$ & $\begin{array}{l}\mathbf{D E} \\
\mathrm{cm}\end{array}$ & $\begin{array}{l}\mathbf{D C} \\
\mathrm{cm}\end{array}$ & $\begin{array}{l}\mathbf{L E} \\
\mathrm{cm}\end{array}$ & $\begin{array}{l}\text { WS } \\
\mathrm{g}\end{array}$ & $\begin{array}{l}\text { DWC } \\
\mathrm{g}\end{array}$ & $\begin{array}{l}\mathbf{D W G}^{+} \\
\mathrm{kg}\end{array}$ & $\begin{array}{l}\% \mathrm{~S} \\
\%\end{array}$ & $\begin{array}{l}\text { GY } \\
\mathrm{kg} \mathrm{ha}^{-1}\end{array}$ \\
\hline Hybrids $(\mathrm{H})$ & 2 & * & * & NS & NS & * & * & * & NS & NS & NS \\
\hline Treatments $(\mathrm{T})$ & 3 & NS & NS & * & * & * & * & * & NS & NS & * \\
\hline $\mathrm{H} / \mathrm{T}$ & 6 & NS & NS & NS & NS & * & NS & NS & NS & NS & NS \\
\hline $\mathrm{R}^{2}$ & & 0.69 & 0.56 & 0.61 & 0.65 & 0.88 & 0.83 & 0.65 & 0.82 & 0.46 & 0.78 \\
\hline CV \% & & 23.4 & 21.7 & 9.7 & 5.9 & 7.6 & 5.7 & 23.3 & 26.3 & 18.1 & 26.3 \\
\hline
\end{tabular}

+ Transformed data. Values of the mean squares with $(*)$ in bold, are statistically significant $(p<0.05), \mathrm{R}^{2}$ coefficient of determination, CV\% coefficient of variability in percentage. MS estimate of mean squares, $\mathbf{d F}$ degrees of freedom. NE number of ears per sample, $\mathbf{F W E}$ fresh weight of the ear per plant (transformed data), DE diameter of the ear, DC diameter of the cob, LE length of the ear, WS weight of 100 seeds, DWC dry weight of the cob, $\mathbf{D W G} \mathbf{W}^{+}$dry weight of the grain per plant (transformed data), $\% \mathbf{S}$ percentage of plant survival at harvest, $\mathbf{G Y}$ grain yield per hectare.

In the comparison between the maize hybrids shown in Table 4, the cultivars Dekalb7508 and INIA619 outperformed XB8010 in grain yield. INIA619 also statistically outperformed the other two hybrids in dry weight of the crown and in crown length. For its part, XB8010 exceeded the other cultivars in fresh weight of the ear and in weight of 100 seeds. Dekalb7508 and XB8010 had a higher relative number of ears in relation to INIA619. 
Table 4. Grain yield and its components comparison for corn hybrids

\begin{tabular}{|c|c|c|c|c|c|c|c|c|c|c|}
\hline \multicolumn{11}{|c|}{ Yield components } \\
\hline Hybrids & NE & FWE $^{+}$ & DE & DC & LE & WS & DWC & DWG $^{+}$ & $\% \mathrm{~S}$ & GY \\
\hline & $\mathrm{n}$ & g plant & $\mathrm{cm}$ & $\mathrm{cm}$ & $\mathrm{cm}$ & $\mathrm{g}$ & $\mathrm{g}$ & $\mathrm{kg}$ & $\%$ & $\mathrm{~kg} \mathrm{ha}^{-1}$ \\
\hline Dekalb7508 & $32.88 \mathrm{a}$ & $21.96 \mathrm{~b}$ & $4.13 \mathrm{a}$ & $2.33 \mathrm{a}$ & $12.76 \mathrm{~b}$ & $27.63 \mathrm{c}$ & $142.50 \mathrm{~b}$ & $1.97 \mathrm{a}$ & $91.63 \mathrm{a}$ & $7885.00 \mathrm{a}$ \\
\hline XB8010 & $32.00 \mathrm{a}$ & $27.67 \mathrm{a}$ & $3.89 \mathrm{a}$ & $2.27 \mathrm{a}$ & $12.65 \mathrm{~b}$ & $32.25 \mathrm{a}$ & $120.13 \mathrm{~b}$ & $1.70 \mathrm{a}$ & $87.24 \mathrm{a}$ & $6269.44 \mathrm{~b}$ \\
\hline INIA619 & $22.20 \mathrm{~b}$ & $21.31 \mathrm{~b}$ & $3.99 \mathrm{a}$ & $2.34 \mathrm{a}$ & $14.56 \mathrm{a}$ & $30.69 \mathrm{~b}$ & $183.50 \mathrm{a}$ & $1.66 \mathrm{a}$ & $81.51 \mathrm{a}$ & $7592.19 \mathrm{a}$ \\
\hline
\end{tabular}

${ }^{+}$Transformed data. ${ }^{1}$ Means followed by the same letters in a column do not differ significantly by the SK test $(\mathrm{p}<0.05)$

In the comparison between inoculant treatments (Table 5), it is shown that the doses of nitrogen fertilization of 60-120 kg N ha ${ }^{-1}$ to which Azospirillum sp. was inoculated were similar in grain yield to the control without inoculation $\left(180 \mathrm{~kg} \mathrm{~N} \mathrm{ha}^{-1}\right)$ and these treatments outperformed the plots that received the only inoculation with Azospirillum sp., without additional nitrogen fertilization $\left(0 \mathrm{~kg} \mathrm{~N}^{-1}\right)$. Similar effects occurred for the cob dry weight, cob diameter and ear diameter. Only in the case of ear length, it was found that the dose of $120 \mathrm{~kg} \mathrm{~N} \mathrm{ha}^{-1}$ + Azospirillum statistically exceeded the control $\left(180 \mathrm{~kg} \mathrm{~N} \mathrm{ha}^{-1}\right)$ and the dose of $60 \mathrm{~kg} \mathrm{~N} \mathrm{ha}^{-1}+$ Azospirillum, existing interaction between maize hybrids and inoculant treatments.

Table 5. Grain yield and its components comparison for inoculant-N fertilization treatments

\begin{tabular}{|c|c|c|c|c|c|c|c|c|c|c|}
\hline \multicolumn{11}{|c|}{ Yield components } \\
\hline Treatments & NE & $\mathbf{F W E}^{+}$ & DE & DC & $\mathbf{L E}$ & WS & DWC & DWG $^{+}$ & $\% \mathrm{~S}$ & GY \\
\hline & $\mathrm{n}$ & g plant & $\mathrm{cm}$ & $\mathrm{cm}$ & $\mathrm{cm}$ & $\mathrm{g}$ & $\mathrm{g}$ & $\mathrm{kg}$ & $\%$ & $\mathrm{~kg} \mathrm{ha}^{-1}$ \\
\hline $60 \mathrm{~N}+\mathrm{A}$ & $31,50 \mathrm{a}$ & $24,04 \mathrm{a}$ & $3,99 \mathrm{a}$ & $2,25 \mathrm{~b}$ & $13,05 \mathrm{~b}$ & $29,00 \mathrm{a}$ & $147,83 \mathrm{a}$ & $1,82 \mathrm{a}$ & $85,01 \mathrm{a}$ & $7124,92 \mathrm{a}$ \\
\hline $120 N+A$ & $31,25 \mathrm{a}$ & $23,82 \mathrm{a}$ & $4,22 \mathrm{a}$ & $2,37 \mathrm{a}$ & $14,54 \mathrm{a}$ & $30,00 \mathrm{a}$ & $164,17 \mathrm{a}$ & $1,84 \mathrm{a}$ & 92,96 a & 8478,08 a \\
\hline $\mathbf{0} \mathbf{N}+\mathbf{A}$ & $27,45 \mathrm{a}$ & $23,36 \mathrm{a}$ & $3,65 \mathrm{~b}$ & $2,23 \mathrm{~b}$ & $11,41 \mathrm{c}$ & $31,33 \mathrm{a}$ & $112,67 \mathrm{~b}$ & $1,62 \mathrm{a}$ & $80,38 \mathrm{a}$ & $5232,75 \mathrm{~b}$ \\
\hline $180 \mathrm{~N}$ & $26,33 \mathrm{a}$ & $23,36 \mathrm{a}$ & $4,14 \mathrm{a}$ & $2,39 \mathrm{a}$ & $14,29 \mathrm{a}$ & $30,42 \mathrm{a}$ & $170,17 \mathrm{a}$ & $1,81 \mathrm{a}$ & 88,83 a & $8159,75 \mathrm{a}$ \\
\hline
\end{tabular}

${ }^{+}$Transformed data. ${ }^{1}$ Means with different letters are statistically significant $(\mathrm{p}<0.05)$

\subsection{Agronomic Characters}

Among the agronomic traits evaluated (Table 6), the effect of inoculant treatments was significant for leaf width (LW), stem diameter (SD), fresh weight of foliage at 30 (FE30), 60 (FE60) and 90 (FE90) days, as well as for foliage dry weight at 30 (DW30) and 60 (DW60) days; In this last variable, a significant interaction was also found between corn hybrids and inoculant treatments. Regarding the maize hybrids evaluated, the significant differences corresponded to the width of the leaf, dry weight of the foliage at 90 days and dry weight of the foliage at 30 and 60 days. No differences were found between the hybrids regarding leaf length, fresh weight at 30 and 60 days, as well as in the percentage of the emergence of the plants.

Table 6. Analysis of Variance for agronomic traits

\begin{tabular}{llllllllllll}
\hline \multicolumn{10}{c}{ MS (Agronomic traits) } \\
\hline Sources of Variation & $\mathbf{d F}$ & $\mathbf{\%} \mathbf{E}$ & $\mathbf{N L P}$ & $\mathbf{L L}$ & $\mathbf{L W}$ & $\mathbf{S D}$ & $\mathbf{F W 3 0}$ & $\mathbf{F W 6 0}$ & $\mathbf{F W 9 0}$ & $\mathbf{D W 3 0}$ & $\mathbf{D W 6 0}$ \\
& & $\%$ & $\mathrm{n}$ & $\mathrm{cm}$. & $\mathrm{cm}$. & $\mathrm{cm}$. & $\mathrm{kg}$ & $\mathrm{kg}$ & $\mathrm{kg}$ & $\mathrm{kg}$ & $\mathrm{kg}$ \\
Hybrids (H) & 2 & $\mathrm{NS}$ & $*$ & $\mathrm{NS}$ & $*$ & $*$ & $\mathrm{NS}$ & $\mathrm{NS}$ & $*$ & $*$ & $*$ \\
Treatments(T) & 3 & $\mathrm{NS}$ & $\mathrm{NS}$ & $\mathrm{NS}$ & $*$ & $*$ & $*$ & $*$ & $*$ & $*$ & $*$ \\
$\mathrm{H} / \mathrm{T}$ & 6 & $\mathrm{NS}$ & $\mathrm{NS}$ & $\mathrm{NS}$ & $\mathrm{NS}$ & $\mathrm{NS}$ & $\mathrm{NS}$ & $\mathrm{NS}$ & $\mathrm{NS}$ & $\mathrm{NS}$ & $*$ \\
$\mathrm{R}^{2}$ & & 0.39 & 0.75 & 0.87 & 0.86 & 0.65 & 0.8 & 0.72 & 0.83 & 0.73 & 0.79 \\
$\mathrm{CV} \%$ & & 4.6 & 10.9 & 8.9 & 10.2 & 13.6 & 23.2 & 24.3 & 23.9 & 32.2 & 22.9 \\
\hline
\end{tabular}

Values of the mean squares with $(*)$ in bold are statistically significant $(p<0.05), \mathrm{R}^{2}$ coefficient of determination, $\mathrm{CV} \%$ coefficient of variability in percentage. MS estimate of mean squares, $\mathrm{dF}$ degrees of freedom. \% $\mathrm{E}$ field emergence percentage 7 days after planting, NLP umber of leaves per plant, LL leaf length, LW leaf width, SD stem diameter, FW30 fresh weight of foliage at 30 days, FW60 fresh weight of foliage at 60 days, FW90 fresh weight of foliage at 90 days, DW30 fresh weight of foliage at 30 days, DW60 fresh weight of foliage at 60 days.

In the comparison between the maize hybrids shown in Table 7, Dekalb7508 surpassed the other two cultivars evaluated in leaf length, but was similar to the cultivar XB 8010 in terms of stem diameter, number of leaves per plant and in dry weight of the foliage at 30 days. Likewise, Dekalb 7506 was statistically similar to INIA 619 
with respect to the dry weight of the foliage at 60 days; INIA 619 outperformed the other two cultivars in the case of fresh weight of the foliage at 90 days.

Table 7. Comparison of agronomic traits for corn hybrids

\begin{tabular}{|c|c|c|c|c|c|c|c|c|c|c|}
\hline \multicolumn{11}{|c|}{ Agronomic traits } \\
\hline Hybrids & $\begin{array}{l}\text { \%E } \\
\%\end{array}$ & $\begin{array}{l}\mathbf{N L P} \\
\mathrm{n}\end{array}$ & $\begin{array}{l}\mathbf{L L} \\
\mathrm{cm} .\end{array}$ & $\begin{array}{l}\mathbf{L W} \\
\mathrm{cm} .\end{array}$ & $\begin{array}{l}\text { SD } \\
\mathrm{cm} .\end{array}$ & $\begin{array}{l}\text { FW30 } \\
\mathrm{kg}\end{array}$ & $\begin{array}{l}\text { FW60 } \\
\mathrm{kg}\end{array}$ & $\begin{array}{l}\text { FW90 } \\
\mathrm{kg}\end{array}$ & $\begin{array}{l}\text { DW30 } \\
\mathrm{kg}\end{array}$ & $\begin{array}{l}\text { DW60 } \\
\mathrm{kg}\end{array}$ \\
\hline & 94,44 c & $9,32 \mathrm{a}$ & $49,13 \mathrm{a}$ & $6,77 \mathrm{a}$ & $1,77 \mathrm{a}$ & $345,56 \mathrm{a}$ & $442,19 \mathrm{a}$ & $1925,13 \mathrm{~b}$ & 90,56 a & $210,31 \mathrm{a}$ \\
\hline $\mathrm{XB}$ & $95,75 \mathrm{a}$ & $9,71 \mathrm{a}$ & $44,91 \mathrm{~b}$ & $5,18 \mathrm{~b}$ & $1,65 \mathrm{a}$ & 329 & 486 & 126 & 88, & $162,81 \mathrm{~b}$ \\
\hline INIA619 & $94,75 \mathrm{a}$ & $7,99 \mathrm{~b}$ & $35,09 \mathrm{c}$ & $5,60 \mathrm{~b}$ & $1,48 \mathrm{~b}$ & $301,75 \mathrm{a}$ & $440,94 \mathrm{a}$ & 2458,13 a & $59,97 \mathrm{~b}$ & $215,81 \mathrm{a}$ \\
\hline
\end{tabular}

${ }^{1}$ Means with different letters are statistically significant $(\mathrm{p}<0.05)$

In the comparison between inoculant treatments for agronomic characters (Table 8), it is shown that the doses of nitrogen fertilization of $60-120 \mathrm{~kg} \mathrm{~N} \mathrm{ha}^{-1}$ inoculated with Azospirillum sp., were similar to the control without inoculation $\left(180 \mathrm{~kg} \mathrm{~N} \mathrm{ha}^{-1}\right)$ and these treatments surpassed the plots that received the only inoculation with Azospirillum sp. without additional nitrogen fertilization $\left(0 \mathrm{~kg} \mathrm{~N} \mathrm{ha}^{-1}\right)$, with respect to the characters of length and width of the leaf, stem diameter, fresh weight of the foliage at 90 days as well as for the dry weight of the foliage at 30 and 60 days.

Table 8. Comparison of agronomic traits for inoculant-N fertilization treatments

\begin{tabular}{lllllllllll}
\hline \multicolumn{1}{l}{ Agronomic traits } & & & & & & & & \\
\hline Treatments & $\mathbf{\%} \mathbf{E}$ & $\mathbf{N L P}$ & $\mathbf{L L}$ & $\mathbf{L W}$ & $\mathbf{S D}$ & $\mathbf{F W ~ 3 0}$ & $\mathbf{F W ~ 6 0}$ & $\mathbf{F W ~ 9 0}$ & $\mathbf{D W ~ 3 0}$ & $\mathbf{D W ~ 6 0}$ \\
& $\%$ & $\mathrm{n}$ & $\mathrm{cm}$. & $\mathrm{cm}$. & $\mathrm{cm}$. & $\mathrm{kg}$ & $\mathrm{kg}$ & $\mathrm{kg}$ & $\mathrm{kg}$ & $\mathrm{kg}$ \\
$\mathbf{6 0} \mathbf{N}+\mathbf{A}$ & $97,33 \mathrm{a}$ & $8,87 \mathrm{a}$ & $44,42 \mathrm{a}$ & $6,13 \mathrm{a}$ & $1,75 \mathrm{a}$ & $245,33 \mathrm{~b}$ & $389,17 \mathrm{~b}$ & $1846,83 \mathrm{a}$ & $95,17 \mathrm{a}$ & $221,42 \mathrm{a}$ \\
$\mathbf{1 2 0} \mathbf{N}+\mathbf{A}$ & $93,17 \mathrm{a}$ & $9,35 \mathrm{a}$ & $43,94 \mathrm{a}$ & $5,90 \mathrm{a}$ & $1,64 \mathrm{a}$ & $344,75 \mathrm{a}$ & $398,75 \mathrm{~b}$ & $2056,67 \mathrm{a}$ & $86,46 \mathrm{a}$ & $208,33 \mathrm{a}$ \\
$\mathbf{0 ~ N}+\mathbf{A}$ & $95,00 \mathrm{a}$ & $8,63 \mathrm{a}$ & $38,77 \mathrm{~b}$ & $5,13 \mathrm{~b}$ & $1,45 \mathrm{~b}$ & $408,33 \mathrm{a}$ & $555,42 \mathrm{a}$ & $1364,17 \mathrm{~b}$ & $51,58 \mathrm{~b}$ & $127,17 \mathrm{~b}$ \\
$\mathbf{1 8 0} \mathbf{N}$ & $94,42 \mathrm{a}$ & $9,18 \mathrm{a}$ & $45,05 \mathrm{a}$ & $6,25 \mathrm{a}$ & $1,69 \mathrm{a}$ & $304,00 \mathrm{~b}$ & $483,33 \mathrm{a}$ & $2260,83 \mathrm{a}$ & $84,83 \mathrm{a}$ & $228,33 \mathrm{a}$ \\
\hline
\end{tabular}

${ }^{1}$ Means with different letters are statistically significant $(p<0.05)$

\section{Discussion}

In the present research, it was found that the grain yield in corn with the control dose $\left(180 \mathrm{~kg} \mathrm{~N} \mathrm{ha}^{-1}\right)$ without inoculation, was similar to that of the doses of $60-120 \mathrm{~kg} \mathrm{~N} \mathrm{ha}^{-1}$ inoculated with the strain of Azospirillum sp. 15 and 45 days after sowing, for the hybrid cultivars evaluated. This result is consistent with the findings of various authors (Galindo et al. 2020; Schmidt \& Gaudin, 2018; Alvarado et al. 2018; Piscoya \& Ugaz, 2016), which indicate an improvement in corn grain yield under the effect of inoculation with Azospirillum sp. The results obtained also seem to agree with other researchers (Zambonin et al. 2019) regarding the little interaction of the inoculant effect of Azospirillum sp. with maize genotypes or hybrids, although there could be certain interaction effects between both factors for some physiological attributes (Silva et al. 2020), evidence also shown by Ferrerira et al (2020), who found that maize hybrids showed greater expressivity in yield components in the presence of A. brasilense applied in seed treatment. Likewise, Alvarado et al. (2018), argue that the joint use of synthetic fertilizers with microbial inoculants increases grain yield in various varieties of hybrid corn, which shows evidence similar to that obtained in the research.

Regarding other characteristics that are considered grain yield components evaluated in the experiment, such as ear diameter and length and seed weight, these were significantly affected by inoculation with Azospirillum sp., although other variables such as the number of ears and fresh weight of the cob, had no effect by inoculation. The significance of the variance components show in this case that the effect of treatments was similar to or greater than the effect of the corn hybrids per se, which suggests that the response in grain yield in the corn cultivars may be balanced with nitrogen fertilization and inoculation with Azospirillum sp.; this aspect has been studied by Wagner et al. (2020) who demostrated that interactions with soil microorganisms are important for the expression of heterosis in corn.

Azospirillum spp. and other bacterial strains have the ability to fix atmospheric nitrogen, solubilize phosphorus or produce growth regulators (Perez-Montano et al. 2013; Schmidt \& Gaudin, 2018), and there is evidence that they can be used as biofertilizers in a complementary way to the application of chemical fertilizers (Alvarado et al. 2018), a fact that is corroborated in this research under the conditions of the Peruvian coast, in which alluvial 
soils devoid of organic matter and scarce in water predominate (Yang, 2020).

The intensive use of fertilizers and phytosanitary agents can increase the rate of nutrients and/or toxic agents in rivers and soils, observing that modern intensive agriculture can strongly impact traditional agriculture in desert areas (Lacroix et al. 2020); environmental impacts are influenced by the high energy intensity linked to the production of inorganic fertilizers used and by phytosanitary agents (Vazquez-Rowe et al. 2016), in that sense, this research can be considered a contribution to evaluate different alternatives of nitrogen fertilization in corn that includes the use of the soil microbiota such as Azospirillum sp. since hard yellow corn is a product in high demand and in deficit in Peruvian agribusiness (Eguren, 2003).

\section{Conclusion}

It was found that for the dose of $180 \mathrm{~kg} \mathrm{ha}^{-1}$ of nitrogen, the grain yield in maize hybrid was similar to that of the plots applied with 60-120 $\mathrm{kg} \mathrm{ha}^{-1}$ of nitrogen fertilization inoculated with Azospirillum sp. Similar responses were found in other components of grain yield and no differences were found in grain yield attributed to interactions between maize hybrids and the application of Azospirillum sp. It is suggested to explore the study of the characterization of the Azospirillum sp. and the impact of the use of this microorganism in the production system of maize.

\section{Acknowledgements}

To the participation of the staff of the Laboratorio de Biotecnología de la Produccion of the National University Jose Faustino Sanchez Carrion (Huacho, Peru) for their collaboration in the isolation, conservation and formulation of the inoculants of Azospirillum sp. for the experiment, especially Jean Piere Quiliche and Pedro Rodríguez. Authors contributed equally to this study and declare no conflicts of interest.

\section{References}

Alvarado, R., Aceves, E., Guerrero, J., Olvera, J. I., Bustamante, A., Vargas S., \& Hernandez, J. H. (2018). Response of maize genotypes (Zea mays L.) to different fertilizers sources in the Valley of Puebla. Terra Latinoamericana, 36(1), 49-59. https://doi.org/10.28940/terra.v36i1.309

Bennett, A. B., Pankievicz, V. C., \& Ane, J. M. (2020). A Model for Nitrogen Fixation in Cereal Crops. Trends in Plant Science, 25(3), 226-235. https://doi.org/10.1016/j.tplants.2019.12.004

Cabrera-Chavez, A. (2020). Manual Tecnico del Cultivo de Maíz Amarillo Duro. Instituto Nacional de Innovacion Agraria. Direccion de Desarrollo Tecnologico Agrario INIA: Lima.

Coniglio, A., Lopez, G., Gualpa, J., Molina, R., Rosas, S., Puente, M., ...\& Cassán, F. (2020). Desarrollo de marcadores moleculares del tipo SCAR para la identificacion de Azospirillum brasilense Az39. Revista Argentina de Microbiología, 52(1), 50-60. https://doi.org/10.1016/j.ram.2019.02.004

Correa-Galeote, D., Bedmar, E. J., Fernández-Gonzalez, A. J., Fernandez-Lopez, M., \& Arone, G. J. (2016). Bacterial communities in the rhizosphere of amilaceous maize (Zea mays L.) as assessed by pyrosequencing. Frontiers in plant science, 7, 1016. https://doi.org/10.3389/fpls.2016.01016

Dellagi, A., Quillere, I., \& Hirel, B. (2020). Beneficial soil-borne bacteria and fungi: a promising way to improve plant nitrogen acquisition. Journal of Experimental Botany, 71(15), 4469-4479. https://doi.org/10.1093/jxb/eraa112

Eguren, F. (2003). La agricultura de la costa peruana. Debate agrario, 35, 1-38.

Ferreira, L. L., Santos, G. F., Carvalho, I. R., de Sa Fernandes, M., Carnevale, A. B., Lopes, K., ... da Silva Curvêlo, C. R. (2020). Cause and effect relationships, multivariate approach for inoculation of Azospirillum brasilense in corn. Communications in Plant Sciences, 10, 37-45. https://doi.org/10.26814/cps2020006

França, S., Mielniczuk, J., Rosa, L. M. G., Bergamaschi, H., \& Bergonci, J. I. (2011). Nitrogênio disponível ao milho: Crescimento, absorção e rendimento de grãos. Revista Brasileira de Engenharia Agrícola e Ambiental, 15, 1143-1151. https://doi.org/10.1590/S1415-43662011001100006

Galindo, F. S., Teixeira Filho, M. C. M., Buzetti, S., Rodrigues, W. L., Fernandes, G. C., Boleta, E. H. M., \& Gaspareto, R. N. (2020). Influence of Azospirillum brasilense associated with silicon and nitrogen fertilization on macronutrient contents in corn. Open Agriculture, 5(1), 126-137. https://doi.org/10.1515/opag-2020-0013

Galindo, F. S., Teixeira Filho, M. C. M., Buzzetti, S., Santini, J. M. K., Alves, C. J., Nogueira, L. M., ... Bellotte, J. L. M. (2016). Corn yield and foliar diagnosis affected by nitrogen fertilization and inoculation with Azospirillum brasilense. Revista Brasileira de Ciência do Solo, 40, e0150364. 
https://doi.org/10.1590/18069657rbcs20150364

Garreaud, R. D. (2009). The Andes climate and weather. Advances in Geosciences, 22, 3-11. https://doi.org/10.5194/adgeo-22-3-2009

Gouda, S., Kerry, R. G., Das, G., Paramithiotis, S., Shin, H. S., \& Patra, J. K. (2018). Revitalization of plant growth-promoting rhizobacteria for sustainable development in agriculture. Microbiological Research, 206, 131-140. https://doi.org/10.1016/j.micres.2017.08.016

Lacroix, P., Dehecq, A., \& Taipe, E. (2020). Irrigation-triggered landslides in a Peruvian desert caused by modern intensive farming. Nature Geoscience, 13(1), 56-60. https://doi.org/10.1038/s41561-019-0500-x1*,

Martin, F. M., Uroz, S., \& Barker, D. G. (2017). Ancestral alliances: plant mutualistic symbioses with fungi and bacteria. Science, 356(6340). https://doi.org/10.1126/science.aad4501

Ministerio de Agricultura y Riego-MINAGRI. (2017). Boletin Estadistico de produccion agricola y ganadera. IV Trimestre 2017. SIEA. Ministerio de Agricultura y Riego. Lima. pp. 174.

Morris, T., Murrell, S., Beegle, D. B., Camberato, J. J., Ferguson, R. B., Grove, J., .. Yang, H. (2018). Strengths and Limitations of Nitrogen Rate Recommendations for Corn and Opportunities for Improvement. Agronomy Journal, 110, 1-17. https://doi.org/10.2134/agronj2017.02.0112

Mueller, U. G., \& Sachs, J. L. (2015). Engineering Microbiomes to Improve Plant and Animal Health. Trends in microbiology. https://doi.org/10.1016/j.tim.2015.07.009

Ngoune Tandzi, L., \& Mutengwa, C. S. (2020). Estimation of maize (Zea mays L.) yield per harvest area: appropriate methods. Agronomy, 10(1), 29. https://doi.org/10.3390/agronomy 10010029

Peiffer, J. A., Spor, A., Koren, O., Jin, Z., Tringe, S. G., Dangl, J. L., Buckler, E., \& Ley, R. E. (2013). Diversity and heritability of the maize rhizosphere microbiome under field conditions. Proceedings of the National Academy of Sciences, 110(16), 6548-6553. https://doi.org/10.1073/pnas.1302837110

Perez-Montano, F., Alias-Villegas, C., Bellogin, R. A., Del Cerro, P., Espuny, M. R., Jimenez-Guerrero, I., ... Cubo, T. (2014). Plant growth promotion in cereal and leguminous agricultural important plants: from microorganism capacities to crop production. Microbiological research, 169(5-6), 325-336. https://doi.org/10.1016/j.micres.2013.09.011

Picazevicz, A. A., Kusdra, J. F., \& Moreno, A. D. L. (2017). Maize growth in response to Azospirillum brasilense, Rhizobium tropici, molybdenum and nitrogen. Revista Brasileira de Engenharia Agricola e Ambiental, 21(9), 623-627. http://dx.doi.org/10.1590/1807-1929/agriambi.v23n11p840-846

Piscoya, E., \& Ugaz, Z. (2016). Efecto de Azospirillum, Azotobacter y Enterobacter spp. nativas con 50\% de fertilizante quimico en el desarrollo vegetativo y rendimiento de Zea mays L. "maiz amarillo duro" en Lambayeque, 2013. Tesis de Biologia. Universidad Nacional Pedro Ruiz Gallo, Chiclayo. Retrieved from http://repositorio.unprg.edu.pe/handle/UNPRG/497

Polk, M. H., Mishra, N. B., Young, K. R., \& Mainali, K. (2020). Greening and Browning Trends across Peru's Diverse Environments. Remote Sensing, 12, 2418. https://doi.org/10.3390/rs12152418

Ramakrishna, W., Yadav, R., \& Li, K. (2019). Plant growth-promoting bacteria in agriculture: Two sides of a coin. Applied Soil Ecology, 138, 10-18. https://doi.org/10.1016/j.apsoil.2019.02.019

Reis, V. M., Alves, B. J. R., Hartmann, A., James, E. K., \& Zilli, J. E. (2020). Beneficial microorganisms in agriculture: the future of plant growth-promoting rhizobacteria. Plant and Soil, 451, 1-3. https://doi.org/10.1007/s11104-020-04482-8

Rosenblueth, M., Ormeno-Orrillo, E., Lopez-Lopez, A., Rogel, M. A., Reyes-Hernandez, B. J., Martinez-Romero, J. C., Reddy, P., \& Martinez-Romero, E. (2018). Nitrogen fixation in cereals. Frontiers in Microbiology, 9, 1794. https://doi.org/10.3389/fmicb.2018.01794

Schaefer, P. E., Martin, T. N., Pizzani, R., \& Schaefer, E. L. (2019). Inoculation with Azospirillum brasilense on corn yield and yield components in an integrated crop-livestock system. Acta Scientiarum. Agronomy, 41, e39481. https://doi.org/10.4025/actasciagron.v41i1.39481

Schmidt, J. E., \& Gaudin, A. C. (2018). What is the agronomic potential of biofertilizers for maize? A meta-analysis. FEMS microbiology ecology, 94(7), fiy094. https://doi.org/10.1093/femsec/fiy094

Silva Barbosa, M., Rodrigues, E. P., Stolf-Moreira, R., Tischer, C. A., \& Martinez de Oliveira, A. L. (2020). Root exudate supplemented inoculant of Azospirillum brasilense Ab-V5 is more effective in enhancing 
rhizosphere colonization and growth of maize. Environmental Sustainability, 3, 187-197. https://doi.org/10.1007/s42398-020-00103-3

Sistema Integrado de Estadistica Agraria. (2020). Encuesta Nacional de Intenciones de Siembra 2019. Ministerio de Agricultura y Riego, SIEA-MINAGRI. Retrieved from http://siea.minagri.gob.pe/siea/sites/default/files/Libro\%20Resultado\%20ENIS\%202019-2020_260719.pdf

Skonieski, F. R., Viegas, J., Martin, T. N., Mingotti, C. C. A., Naetzold, S., Tonin, T. J., ... Meinerz, G. R. (2019). Effect of Nitrogen Topdressing Fertilization and Inoculation of Seeds with Azospirillum brasilense on Corn Yield and Agronomic Characteristics. Agronomy, 9, 812. https://doi.org/10.3390/agronomy9120812

Van Deynze, A., Zamora, P., Delaux, P. M., Heitmann, C., Jayaraman, D., Rajasekar, S., ... Berry, A. M. (2018). Nitrogen fixation in a landrace of maize is supported by a mucilage-associated diazotrophic microbiota. PLoS biology, 16(8), e2006352. https://doi.org/10.1371/journal.pbio.2006352

Vazquez-Rowe, I., Kahhat, R., Quispe, I., \& Bentin, M. (2016). Environmental profile of green asparagus production in a hyper-arid zone in coastal Peru. Journal of Cleaner Production, 112, 2505-2517. https://doi.org/10.1016/j.jclepro.2015.09.076

Wagner, M. R., Tang, C., Salvato, F., Clouse, K. M., Bartlett, A., Sermons, S., Hoffmann, M., Balint-Kurti, P. J., \& Kleiner, M. (2020). Microbe-dependent heterosis in maize. bioRxiv. https://doi.org/10.1101/2020.05.05.078766

Walters, W. A., Jin, Z., Youngblut, N., Wallace, J. G., Sutter, J., Zhang, W., ... Knight, R. (2018). Large-scale replicated field study of maize rhizosphere identifies heritable microbes. Proceedings of the National Academy of Sciences, 115(28), 7368-7373. https://doi.org/10.1073/pnas.1800918115

Yang, S. (2020). Soil organic matter in the Peruvian Andes: Unravelling factors controlling soil organic carbon distribution and the underlying organic matter stabilization mechanisms. University of Amsterdam. UvA-DARE Digital Academic Repository.

Zambonin, G., Pacentchuk, F., Lima, F. N., Huzar-Novakowiski, J., \& Sandini, I. E. (2019). Response of maize crop hybrids, with different transgenic events, to inoculation with Azospirillum brasilense. Applied Research \& Agrotechnology, 12(1), 33-40. https://doi.org/10.5935/PAeT.V12.N1.03

\section{Copyrights}

Copyright for this article is retained by the author(s), with first publication rights granted to the journal.

This is an open-access article distributed under the terms and conditions of the Creative Commons Attribution license (http://creativecommons.org/licenses/by/3.0/). 